\title{
Synthesis and Bioactivity of Quinone Mono- and Dioxime Salts
}

\author{
Svetlana Konovalova ${ }^{1(\mathbb{D})}$, Anatoly Avdeenko ${ }^{1, *(\mathbb{D})}$, Diana Baranovych ${ }^{2(\mathbb{D})}$, Vira Lubenets ${ }^{2(\mathbb{D})}$ \\ 1 Chemistry Department, Donbass State Engineering Academy, Akademichna Str., 72, Kramatorsk, 84313, Ukraine; \\ chimist@dgma.donetsk.ua (S.K.); \\ 2 Department of Technology of Biologically Active Substances, Pharmacy \& Biotechnology, Lviv National Polytechnic \\ University, S. Bandery Str. 12, Lviv, Ukraine; diana.b.baranovych@gmail.com (D.B.); vlubenets@ gmail.com (V.L.) \\ * Correspondence: chimist@dgma.donetsk.ua;
}

Scopus Author ID 7004960551

Received: 17.04.2020; Revised: 10.05.2020; Accepted: 10.05.2020; Published: 12.05.2020

\begin{abstract}
Eliminating all kinds of harmful organisms is an important task in agriculture, food production, and human life. Quinone oximes and their salts are good bioactive compounds to attain this aim. The alkali metal salts of quinone mono- and dioxime have been synthesized by the reaction of the corresponding quinone oxime with alkali metal hydroxide. The divalent metal salts have been obtained in two stages. The first stage is the synthesis of the sodium salt of the quinone oxime. The second step is the reaction of the latter with a divalent metal salt. Copper and zinc salts of [(4-oxocyclohexa-2,5dien-1-ylidene)amino]oxidanide have the highest insecticidal activity against the housefly and rice weevil. The death index is 90-100\%. Copper \{[2-methyl-4-oxo-5-(propan-2-yl)cyclohexa-2,5-dien-1ylidene]amino \}oxidanide shows good activity against Phytophthora infestans. Inhibition of the growth and development of the Phytophthora infestans is $80 \%$.
\end{abstract}

Keywords: quinone; quinone monooxime; quinone dioxime; alkali metal salt; copper salt; zinc salt; insecticide; fungicide.

(C) 2020 by the authors. This article is an open access article distributed under the terms and conditions of the Creative
Commons Attribution (CC BY) license (https://creativecommons.org/licenses/by/4.0/).

\section{Introduction}

Eliminating all kinds of harmful organisms is an important task in agriculture, food production, and human life. Rice weevils are harmless to human, but they feed on cereals, flour, and cornmeal. The big problem is to keep them out of processes and crops. Aphids are the main pests in agriculture, causing large crop yield losses [1]. Because arachnid mites feed on the plant leaves, they cause a lot of crop losses [2]. Houseflies are carriers of human and animal diseases caused by protozoa, viruses, bacteria, and pathogens. These pathogens are transported by mouthparts, feces, gut, mouth saliva, and the surface of its body. They usually spread harmful pathogens that come into contact with animals and/or human [3].

Various insecticides are used to control pests, but over time, insects become resistant to them [4-9]. Thus, new insecticides against rice weevil [10, 11], aphid [5, 12], arachnid mite [13], and housefly $[3,14,15]$ are being sought. And this task is relevant.

Many of the plant diseases depend on microorganisms. One type of plant can be infected by a few microbial phytopathogen parasitizes.

Fusarium moniliforme produces mycotoxins that cause many diseases. These mycotoxins are common harmful substances found in plants, food, and feed. The presence of mycotoxins is a risk for animal and human health [16]. Xanthomonas is a genus of bacterial 
plant pathogens that cause many diseases in economically important crops [17], for example, cotton gummosis. The fungus Penicillium cyclopium affects cereal products. It produces mycotoxins that affect various crops [18].

It is relevant to use the bioactive substances for the protection of agricultural raw materials and plant products (feed, food) from microorganisms producing mycotoxins, in particular for the prevention of the formation of fungal biofilms [19-22].

Quinone oximes and their salts are good synthons for the synthesis of new biologically active derivatives [23, 24]. Different quinone oximes and their derivatives were synthesized earlier [25, 26]. Quinoid compounds have high persicidal activity [27, 28]. Metals, their complexes and salts are widely used in the applied biological sciences and are bioactive agents [29-31]. Various salts of quinone mono- and dioximes have been synthesized before [32], but their biologic activity has not been studied.

Thus, the purpose of our work is to synthesize new quinone mono- and dioxime salts, which could be used as anti-nematode, insecticidal, and fungicidal agents. We also studied the biologic activity of oxime salts synthesized previously.

\section{Materials and Methods}

\subsection{General experimental details.}

The ${ }^{1} \mathrm{H}$ NMR spectra were measured on the Varian VXR-300 spectrometer (300 MHz) using TMS as an internal standard. DMSO-d6 was used as a solvent. The IR spectra were recorded on a UR-20 spectrometer in $\mathrm{KBr}$. The purity of the reaction products and initial compounds was determined by TLC on Silufol UV-254 plates. Acetone was used as a solvent. A mixture of ethanol and chloroform (1:10) was used as eluent. The spots were developed under UV light. The melting points were uncorrected.

Quinone monooximes 1a-d were synthesized by nitrosation of the corresponding phenols by the procedures reported in [33,34]. Quinone dioxime 6 was obtained by the method described in [35].

Alkali metal salts of [(4-oxocyclohexa-2,5-dien-1-ylidene)amino]oxidanide 2a-d, 3(oxidoimino)-6-oxocyclohexa-1,4-diene-1-carboxylate 4a-c and N,N'-cyclohexa-2,5-diene1,4-diylidenedihydroxylamine 7a-c (general procedure). 0.1 or 0.2 mole of alkali metal hydroxide was added to the mixture of $100 \mathrm{ml}$ of methanol and 0.1 mole of quinone oxime 1ad or oxime 1e, $\mathbf{6}$, respectively. The mixture was refluxed until the initial compounds were completely dissolved. After that, it was cooled and slowly poured with stirring into $700 \mathrm{ml}$ of diethyl ether. The precipitate was filtered off under low pressure, washed with diethyl ether, and dried. The products were colored crystalline substances, which decomposed by heating in a wide temperature range.

Alkali metal salts of 10a-d, 13 were obtained by the analogous procedure.

Characteristics of metal salts 2a-d, 7a-c, 10a-d, 13 correspond to literary data [32].

Dilithium 3-(oxidoimino)-6-oxocyclohexa-1,4-diene-1-carboxylate 4a. Yield $72 \%$; deep-brown crystals; m.p. $>200^{\circ} \mathrm{C}$ (decomposition). $\mathrm{NMR}{ }^{1} \mathrm{H}(\delta$, ppm): Z-isomer, $6.08(\mathrm{~d}, 1 \mathrm{H}$, $\left.\mathrm{H}^{5}, J 8.8 \mathrm{~Hz}\right), 7.82\left(\mathrm{k}, 1 \mathrm{H}, \mathrm{H}^{4}, J\right.$ 8.8, $\left.2.6 \mathrm{~Hz}\right), 7.85\left(\mathrm{~d}, 1 \mathrm{H}, \mathrm{H}^{2}, J 2.6 \mathrm{~Hz}\right) ;$ E-isomer, $5.89(\mathrm{~d}, 1 \mathrm{H}$, $\left.\mathrm{H}^{5}, J 9.6 \mathrm{~Hz}\right), 6.72\left(\mathrm{k}, 1 \mathrm{H}, \mathrm{H}^{4}, J 9.6,3.0 \mathrm{~Hz}\right), 6.77\left(\mathrm{~d}, 1 \mathrm{H}, \mathrm{H}^{2}, J 3.0 \mathrm{~Hz}\right)$. Anal. Calcd. For $\mathrm{C}_{7} \mathrm{H}_{3} \mathrm{Li}_{2} \mathrm{NO}_{4}$ : C, 46.97; N 7.83\%. Found: C, 46.58; N, 7.79\%.

Disodium 3-(oxidoimino)-6-oxocyclohexa-1,4-diene-1-carboxylate 4b. Yield $97 \%$; yellow-brown crystals; m.p. $>200^{\circ} \mathrm{C}$ (decomposition). NMR ${ }^{1} \mathrm{H}(\delta, \mathrm{ppm})$ : Z-isomer, 6.06 (d, 
$\left.1 \mathrm{H}, \mathrm{H}^{5}, J 8.8 \mathrm{~Hz}\right), 7.83\left(\mathrm{k}, 1 \mathrm{H}, \mathrm{H}^{4}, J\right.$ 8.8, $\left.2.6 \mathrm{~Hz}\right), 7.83\left(\mathrm{~d}, 1 \mathrm{H}, \mathrm{H}^{2}, J 2.6 \mathrm{~Hz}\right)$; E-isomer, 5.91 $\left(\mathrm{d}, 1 \mathrm{H}, \mathrm{H}^{5}, J 9.6 \mathrm{~Hz}\right), 6.74\left(\mathrm{k}, 1 \mathrm{H}, \mathrm{H}^{4}, J 9.6,3.0 \mathrm{~Hz}\right), 6.76\left(\mathrm{~d}, 1 \mathrm{H}, \mathrm{H}^{2}, J 3.0 \mathrm{~Hz}\right)$. Anal. Calcd. For $\mathrm{C}_{7} \mathrm{H}_{3} \mathrm{NNa}_{2} \mathrm{O}_{4}$ : C, 39.83; N 6.64\%. Found: C, 40.02; N, 6.55\%.

Dipotassium 3-(oxidoimino)-6-oxocyclohexa-1,4-diene-1-carboxylate 4c. Yield $82 \%$; brown crystals; m.p. $>200^{\circ} \mathrm{C}$ (decomposition). NMR ${ }^{1} \mathrm{H}(\delta, \mathrm{ppm})$ : Z-isomer, $6.07\left(\mathrm{~d}, 1 \mathrm{H}, \mathrm{H}^{5}, J\right.$ $8.8 \mathrm{~Hz}), 7.81\left(\mathrm{k}, 1 \mathrm{H}, \mathrm{H}^{4}, J\right.$ 8.8, 2.6 Hz), $7.82\left(\mathrm{~d}, 1 \mathrm{H}, \mathrm{H}^{2}, J 2.6 \mathrm{~Hz}\right)$; E-isomer, $5.92\left(\mathrm{~d}, 1 \mathrm{H}, \mathrm{H}^{5}\right.$, $J 9.6 \mathrm{~Hz}), 6.75\left(\mathrm{k}, 1 \mathrm{H}, \mathrm{H}^{4}, J\right.$ 9.6, $\left.3.0 \mathrm{~Hz}\right), 6.75\left(\mathrm{~d}, 1 \mathrm{H}, \mathrm{H}^{2}, J 3.0 \mathrm{~Hz}\right)$. Anal. Calcd. For $\mathrm{C}_{7} \mathrm{H}_{3} \mathrm{~K}_{2} \mathrm{NO}_{4}$ : C, 34.56; N 5.76\%. Found: C, 34.64; N, 5.59\%.

Divalent metal salts of [(4-oxocyclohexa-2,5-dien-1-ylidene)amino]oxidanide 3a-h, 3(oxidoimino)-6-oxocyclohexa-1,4-diene-1-carboxylate 5a, b and N,N'-cyclohexa-2,5-diene1,4-diylidenedihydroxylamine 8 (general procedure). 0.1 Mole of quinone monooxime 1a-e or quinone dioxime 6 was dissolved by heating up to $60-70{ }^{\circ} \mathrm{C}$ in $250 \mathrm{ml}$ of water containing 0.1 (for compounds 1a-d) or 0.2 (for compounds 1e, 6) mole of sodium hydroxide. The colored hot solution was filtered. Solution of the corresponding divalent metal salt (sulfate, nitrate, or chloride) in a minimal amount of water was slowly added to the filtrate with stirring. The mixture was cooled and kept for $24 \mathrm{~h}$. The precipitate was filtered off under low pressure, washed with water and methanol, and dried. The products were colored crystalline substances, which decomposed by heating in a wide temperature range.

Copper 3-(oxidoimino)-6-oxocyclohexa-1,4-diene-1-carboxylate 5a. Yield 95\%; black crystals; m.p. $>200^{\circ} \mathrm{C}$ (decomposition). Anal. Calcd. For $\mathrm{C}_{7} \mathrm{H}_{3} \mathrm{CuNO}_{4}$ : C, 36.77; N 6.13\%. Found: C, 36.62; N, 6.22\%.

Zinc 3-(oxidoimino)-6-oxocyclohexa-1,4-diene-1-carboxylate 5b. Yield $98 \%$; green crystals; m.p. $>200^{\circ} \mathrm{C}$ (decomposition). Anal. Calcd. For $\mathrm{C}_{7} \mathrm{H}_{3} \mathrm{NO}_{4} \mathrm{Zn}$ : C, 36.47; N 6.08\%. Found: C, 36.58; N, 6.18\%.

Divalent metal salts of 11,14 were obtained by the analogous procedure.haracteristics of metal salts 3a-h, 8, 11, 14 correspond to literary data [32].

\subsection{Biological studies.}

Biologic activities of compounds were determined in the biological testing laboratory in the Kiev Research Institute Sinteko, OJSC, Ukraine.

\section{Results and Discussion}

Alkali metal salts of [(4-oxocyclohexa-2,5-dien-1-ylidene)amino]oxidanide 2a-d were synthesized in the reaction of 4-(hydroxyimino)cyclohexa-2,5-dien-1-one 1a-d with corresponding alkali metal hydroxide (Scheme 1). In order to synthesize divalent metal salts 3a-h, the reaction was carried out in two stages. First, the sodium salt of corresponding oxidanide was obtained, which was converted into the desired product by reaction with a divalent metal salt solution.
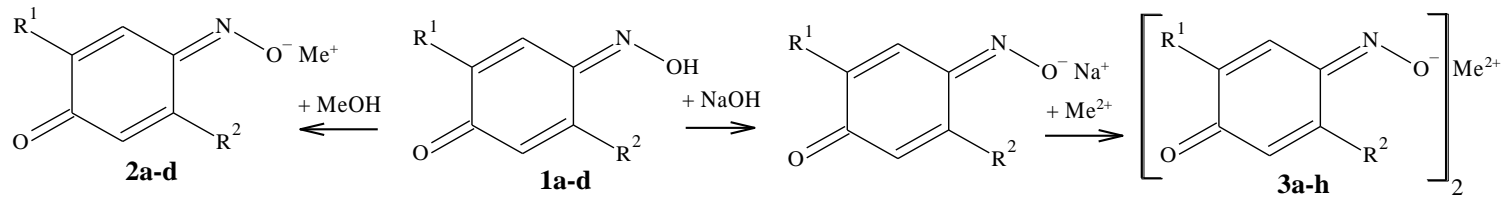

1: $\mathrm{R}^{1}=\mathrm{R}^{2}=\mathrm{H}(\mathbf{a}), \mathrm{R}^{1}=\mathrm{CH}_{3}, \mathrm{R}^{2}=\mathrm{H}(\mathbf{b}), \mathrm{R}^{1}=\mathrm{H}, \mathrm{R}^{2}=\mathrm{CH}_{3}(\mathbf{c}), \mathrm{R}^{1}=i-\mathrm{Pr}, \mathrm{R}^{2}=\mathrm{CH}_{3}(\mathbf{d}) ; \mathbf{2}: \mathrm{R}^{1}=\mathrm{R}^{2}=\mathrm{H}, \mathrm{Me}=\mathrm{Li}(\mathbf{a}), \mathrm{R}^{1}=\mathrm{R}^{2}=\mathrm{H}$, $\mathrm{Me}=\mathrm{K}(\mathbf{b}), \mathrm{R}^{1}=\mathrm{CH}_{3}, \mathrm{R}^{2}=\mathrm{H}, \mathrm{Me}=\mathrm{K}(\mathbf{c}), \mathrm{R}^{1}=i-\mathrm{Pr}, \mathrm{R}^{2}=\mathrm{CH}_{3}, \mathrm{Me}=\mathrm{K}(\mathbf{d}) ; 3: \mathrm{R}^{1}=\mathrm{R}^{2}=\mathrm{H}, \mathrm{Me}=\mathrm{Cu}(\mathbf{a}), \mathrm{R}^{1}=\mathrm{CH}_{3}, \mathrm{R}^{2}=\mathrm{H}$, 
$\mathrm{Me}=\mathrm{Cu}(\mathbf{b}), \mathrm{R}^{1}=\mathrm{H}, \mathrm{R}^{2}=\mathrm{CH}_{3}, \mathrm{Me}=\mathrm{Cu}(\mathbf{c}), \mathrm{R}^{1}=i-\mathrm{Pr}, \mathrm{R}^{2}=\mathrm{CH}_{3}, \mathrm{Me}=\mathrm{Cu}(\mathbf{d}), \mathrm{R}^{1}=\mathrm{R}^{2}=\mathrm{H}, \mathrm{Me}=\mathrm{Zn}(\mathbf{e}), \mathrm{R}^{1}=\mathrm{CH}_{3}, \mathrm{R}^{2}=\mathrm{H}$, $\mathrm{Me}=\mathrm{Zn}(\mathbf{f}), \mathrm{R}^{1}=\mathrm{H}, \mathrm{R}^{2}=\mathrm{CH}_{3}, \mathrm{Me}=\mathrm{Zn}(\mathbf{g}), \mathrm{R}^{1}=i-\mathrm{Pr}, \mathrm{R}^{2}=\mathrm{CH}_{3}, \mathrm{Me}=\mathrm{Zn}(\mathbf{h})$.

Scheme 1. Synthesis of the metal salts of [(4-oxocyclohexa-2,5-dien-1-ylidene)amino]oxidanide 2a-d, 3a-h.

Metal salts of 3-(oxidoimino)-6-oxocyclohexa-1,4-diene-1-carboxylate 4a-c, 5a, b were obtained by the same procedure (Scheme 2 ).

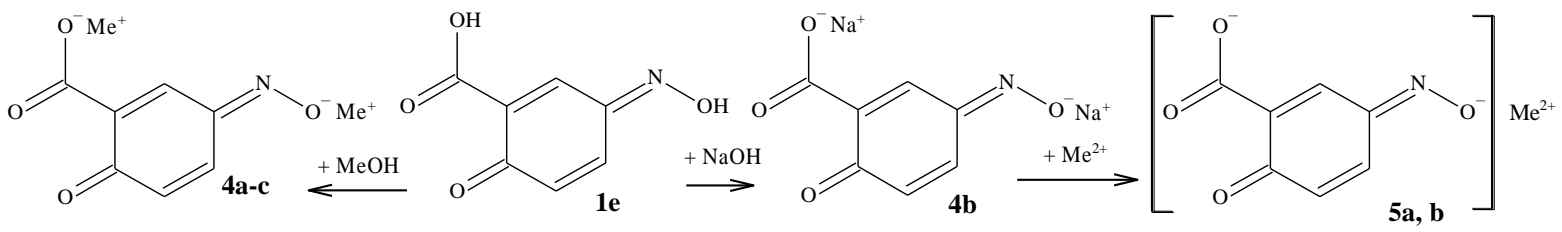

4: $\mathrm{Me}=\mathrm{Li}(\mathbf{a}), \mathrm{Na}(\mathbf{b}), \mathrm{K}(\mathbf{c}) ; \mathbf{5}: \mathrm{Me}=\mathrm{Cu}(\mathbf{a}), \mathrm{Zn}(\mathbf{b})$.

Scheme 2. Synthesis of the metal salts of 3-(oxidoimino)-6-oxocyclohexa-1,4-diene-1-carboxylate 4a-c, 5a, b.

The structures of compounds 4a-c, 5a, b were determined by elemental analysis and IR and NMR ${ }^{1} \mathrm{H}$ spectra. In IR spectra of compounds $4 \mathrm{a}-\mathrm{c}, 5 \mathrm{a}, \mathrm{b}$ the absorption bands were observed in the region of $1580-1665 \mathrm{~cm}^{-1}(\mathrm{C}=\mathrm{O})$ and $1500-1610 \mathrm{~cm}^{-1}(\mathrm{C}=\mathrm{N})$. The salts $5 \mathrm{a}, \mathrm{b}$ were insoluble in organic solvents; therefore, their structures were studied with alkali metal derivatives, which were soluble in many organic solvents.

Alkali metal salts of \{cyclohexa-2,5-diene-1,4-diylidenebis[(E)azanylylidene $]$ bis(oxidanide) 7a-c were synthesized by reaction of $N, N^{\prime}$-cyclohexa-2,5-diene-1,4diylidenedihydroxylamine 6 with corresponding alkali metal hydroxide (Scheme 3).

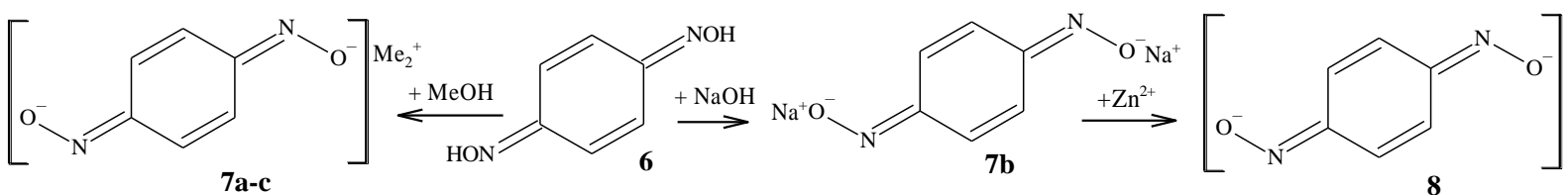

7: $\mathrm{Me}=\mathrm{Li}(\mathbf{a}), \mathrm{Na}(\mathbf{b}), \mathrm{K}(\mathbf{c})$.

Scheme 3. Synthesis of the metal salts of \{cyclohexa-2,5-diene-1,4-diylidenebis[azanylylidene] $\}$ bis(oxidanide)

$7 a-c, 8$.

The divalent metal salt 8 was obtained in two stages: 1) the synthesis of sodium salt $7 \mathrm{~b}$, 2) reaction of sodium salt $7 \mathrm{~b}$ with a divalent metal salt.

We also synthesized naphthalene derivatives of quinone oximes, since various naphthalene derivatives show high biologic activity [36].

Alkali metal salts of [(1-oxonaphthalen-2(1H)-ylidene)amino]oxidanides 10a-d, 11 and [(2-oxonaphthalen-1(2H)-ylidene)amino]oxidanide 13, 14 were synthesized by reaction of corresponding 2-(hydroxyimino)naphthalen-1(2H)-ones 9a,b or 1-(hydroxyimino)naphthalen2(1H)-one 12 with alkali metal hydroxide (scheme 4). The copper salts 11 and 12 were also obtained in two stages.

The metal salts of quinone mono- and dioximes 2a-d, 3a-h, 4a-c, 5a, b, 7a-c, 8, 10a-d, $11,13,14$ were tested for insecticidal and anti-nematode activity.

In order to study the insecticidal activity of these compounds, we used aqueous solutions of the alkali metal salts and aqueous suspensions of the copper and zinc salts. The concentration of the tested compound in the solution was $0.5 \%$ in tests of weevils and flies, $0.01 \%$ in tests of aphids, and $0.1 \%$ in tests of mites. We studied the action of these solutions on house flies (Musca domestica), rice weevils (Sitophilus oryzae), arachnid mites (Tetranychus urticae), and black beet aphids (Aphis fabae Scopoli). 
In the study of anti-nematode activity, the concentration of the tested compound was $80 \mathrm{mg} / \mathrm{kg}$ under soil application.

The results of biological activity studies are shown in Table 1.<smiles>[X]C1=CC(=NO)C(=O)c2ccccc21</smiles>

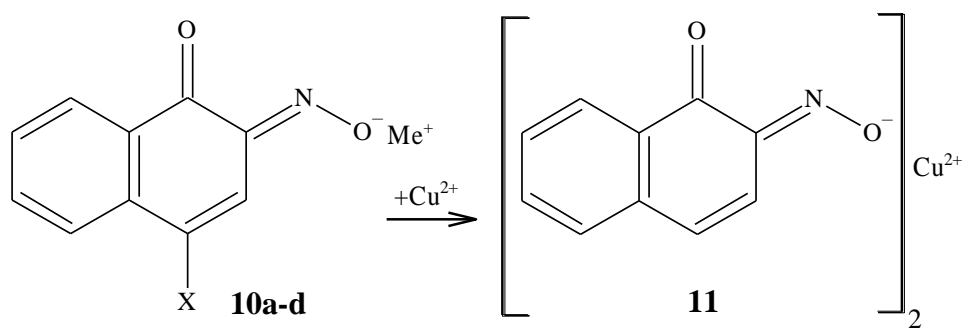<smiles>O=C1C=Cc2ccccc2C1=NO</smiles>

12<smiles>O=C1C=Cc2ccccc2C1=NO[Na]</smiles>

13<smiles>O=C1C=Cc2ccccc2C1/N=C/[O-]</smiles>

9: $\mathrm{X}=\mathrm{H}(\mathbf{a}), \mathrm{SO}_{2} \mathrm{OH}(\mathbf{b}) ; \mathbf{1 0}: \mathrm{X}=\mathrm{H}, \mathrm{Me}=\mathrm{Li}(\mathbf{a}), \mathrm{X}=\mathrm{H}, \mathrm{Me}=\mathrm{K}(\mathbf{b}), \mathrm{X}=\mathrm{SO}_{3} \mathrm{Na}, \mathrm{Me}=\mathrm{Na}(\mathbf{c}) ; \mathrm{X}=\mathrm{SO}_{3} \mathrm{~K}, \mathrm{Me}=\mathrm{K}(\mathbf{d})$.

Scheme 4. Synthesis of the metal salts of [(1-oxonaphthalen-2(1H)-ylidene)amino]oxidanides 10a-d, 11 and [(2-oxonaphthalen-1(2H)-ylidene)amino]oxidanide 13, 14.

Table 1. The test results of insecticidal and anti-nematode activities of compounds $\mathbf{2 a - d , ~ 3 a - h , ~ 4 a - c , ~ 5 a , ~ b , ~ 7 a - c , ~}$ 8, 10a-d, 11, 13, 14.

\begin{tabular}{|c|c|c|c|c|c|}
\hline \multirow{2}{*}{$\begin{array}{c}\text { Compound } \\
\text { number }\end{array}$} & \multicolumn{4}{|c|}{ The death index of insects and mites, \% } & \multirow{2}{*}{$\begin{array}{l}\text { The reduction of } \\
\text { gall formation on } \\
\text { cucumber roots, \% }\end{array}$} \\
\hline & Musca domestica & Sitophilus oryzae & $\begin{array}{c}\text { Tetranychus } \\
\text { urticae }\end{array}$ & $\begin{array}{c}\text { Aphis fabae } \\
\text { Scopoli }\end{array}$ & \\
\hline $2 \mathbf{a}$ & 0 & 0 & 0 & 16 & 0 \\
\hline $2 \mathbf{b}$ & 0 & 18 & 0 & 0 & 0 \\
\hline $2 c$ & 0 & 32 & 0 & 6 & 0 \\
\hline 2d & 0 & 32 & 0 & 6 & 0 \\
\hline $\mathbf{3 a}$ & 4 & 11 & 30 & 0 & 0 \\
\hline 3b & 100 & 62 & 5 & 14 & 73 \\
\hline $3 c$ & 0 & 0 & 26 & 20 & 0 \\
\hline 3d & 8 & 3 & 26 & 3 & 0 \\
\hline $3 e$ & 5 & 18 & 0 & 0 & 0 \\
\hline 3f & 96 & 100 & 13 & 0 & 0 \\
\hline $3 g$ & 100 & 100 & 18 & 19 & 0 \\
\hline $3 h$ & 90 & 100 & 10 & 3 & 6 \\
\hline $4 a$ & 0 & 68 & 0 & 0 & 0 \\
\hline $4 b$ & 0 & 44 & 4 & 7 & 9 \\
\hline $4 c$ & 0 & 35 & 2 & 10 & 0 \\
\hline $5 a$ & 100 & 41 & 3 & 14 & 9 \\
\hline $5 b$ & 0 & 42 & 14 & 0 & 0 \\
\hline $7 \mathbf{a}$ & 0 & 76 & 0 & 0 & 0 \\
\hline $7 b$ & 0 & 62 & 0 & 0 & 0 \\
\hline $7 c$ & 0 & 39 & 60 & 13 & 0 \\
\hline 8 & 0 & 11 & 21 & 17 & 0 \\
\hline $10 \mathrm{a}$ & 0 & 44 & 5 & 0 & 0 \\
\hline $10 \mathrm{~b}$ & 0 & 60 & 11 & 7 & 39 \\
\hline $10 \mathrm{c}$ & 0 & 21 & 7 & 7 & 0 \\
\hline 10d & 0 & 16 & 11 & 7 & 0 \\
\hline 11 & 8 & 0 & 26 & 0 & 0 \\
\hline 13 & 5 & 79 & 8 & 3 & 0 \\
\hline 14 & 10 & 0 & 20 & 10 & 0 \\
\hline
\end{tabular}

In the first stage of screening, we used discriminating concentrations of the test compounds. The compounds $3 \mathrm{~b}, \mathrm{f}-\mathrm{h}, 5 \mathrm{a}$ showed a high insecticidal and miticidal activity. The death rate of Musca domestica and Sitophilus oryzae was 90-100\% (Table 1). The solution of salt $3 \mathrm{~b}$ and $5 \mathrm{a}$ killed $100 \%$ of the housefly. The solutions of salts $3 \mathrm{f}-\mathrm{h}$ killed $90-100 \%$ of both 
housefly and rice weevil. However, with a decrease in the concentration of compounds to $0.05 \%$, insect death did not exceed $42 \%$.

Compounds $4 \mathrm{a}, 7 \mathrm{a}-\mathrm{c}, 10 \mathrm{~b}, 13$ had a relatively high insecticidal and miticidal activity, resulting in $60-85 \%$ death of the tested objects. Other compounds showed no insecticidal activity at all, or their activity was not important.

The nematicidal activity of studied compounds was either very low or completely absent. Only when using salt $3 b$, the reduction of gall formation on cucumber roots was $73 \%$.

All salts 2a-d, 3a-h, 4a-c, 5a, b, 7a-c, 8, 10a-d, 11, 13, and 14 were tested for bactericidal activity. In this investigation, we used eight objects: four types of fungi, which were tested on solid media (Penicillium cyclopium, Fusarium moniliforme, Aspergillus niger, Venturia Inaequalis); one type of bacteria (Xanthomonas malvacearum); three types of fungi, which exist on green plants, gray rot of the beans (Botrytis cinerea), cucumber powdery mildew (Oidium erysiphoides), the late blight of tomatoes (Phytophthora infestans).

The test results of the salts $2 \mathrm{a}-\mathrm{d}, 3 \mathrm{a}-\mathrm{h}, 4 \mathrm{a}-\mathrm{c}, 5 \mathrm{a}, \mathrm{b}, 7 \mathrm{a}-\mathrm{c}, 8,10 \mathrm{a}-\mathrm{d}, 11,13$, and 14 are shown in Table 2.

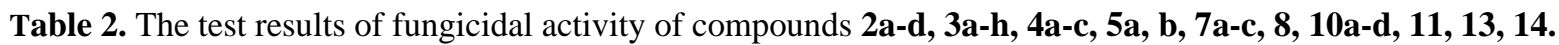

\begin{tabular}{|c|c|c|c|c|c|c|c|c|}
\hline \multirow{4}{*}{$\begin{array}{l}\text { Compoun } \\
\text { d number }\end{array}$} & \multicolumn{8}{|c|}{ Inhibition of the growth and development,\% } \\
\hline & \multicolumn{5}{|c|}{ Colonies of bacteria and fungi, concentration of $0.003 \%$} & \multicolumn{3}{|c|}{ Green plant diseases } \\
\hline & \multirow[b]{2}{*}{$\begin{array}{l}\text { Xanthomonas } \\
\text { malvacearum }\end{array}$} & \multirow[b]{2}{*}{$\begin{array}{c}\text { Fusarium } \\
\text { moniliforme }\end{array}$} & \multirow[b]{2}{*}{$\begin{array}{c}\text { Penicillium } \\
\text { cyclopium }\end{array}$} & \multirow[b]{2}{*}{$\begin{array}{c}\text { Venturia } \\
\text { Inaegualis }\end{array}$} & \multirow[b]{2}{*}{$\begin{array}{c}\text { Aspergillius } \\
\text { niger }\end{array}$} & \multicolumn{2}{|c|}{$\begin{array}{l}\text { Concentration } \\
\text { of } 0.1 \%\end{array}$} & \multirow{2}{*}{$\begin{array}{c}\begin{array}{c}\text { Concentratio } \\
\text { n of } 0.05 \%\end{array} \\
\begin{array}{c}\text { Oidium } \\
\text { erysiphoides }\end{array}\end{array}$} \\
\hline & & & & & & $\begin{array}{c}\text { Phytophthor } \\
\text { a infestans }\end{array}$ & $\begin{array}{l}\text { Botryti } \\
s \\
\text { cinere } \\
a\end{array}$ & \\
\hline $2 a$ & 12 & 18 & 16 & 31 & 22 & 0 & 0 & 0 \\
\hline 2b & 13 & 18 & 0 & 25 & 12 & 0 & 0 & 30 \\
\hline $2 c$ & 20 & 5 & 0 & 18 & 0 & 0 & 0 & 0 \\
\hline 2d & 12 & 24 & 22 & 6 & 22 & 50 & 0 & 43 \\
\hline $3 a$ & 11 & 7 & 5 & 11 & 10 & 45 & 0 & 17 \\
\hline $3 b$ & 14 & 11 & 6 & 18 & 20 & 0 & 0 & 0 \\
\hline $3 c$ & 31 & 20 & 38 & 11 & 5 & 41 & 0 & 19 \\
\hline $3 d$ & 25 & 24 & 22 & 29 & 0 & 80 & 0 & 0 \\
\hline $3 e$ & 0 & 14 & 11 & 12 & 0 & 0 & 0 & 0 \\
\hline $3 f$ & 14 & 19 & 35 & 6 & 12 & 0 & 0 & 0 \\
\hline $3 g$ & 28 & 29 & 47 & 18 & 0 & 0 & 0 & 0 \\
\hline $3 \mathrm{~h}$ & 14 & 12 & 5 & 0 & 0 & 0 & 50 & 0 \\
\hline $4 a$ & 18 & 9 & 16 & 12 & 5 & 0 & 0 & 0 \\
\hline $4 b$ & 6 & 21 & 5 & 0 & 5 & 54 & 50 & 40 \\
\hline $4 c$ & 25 & 27 & 5 & 6 & 11 & 54 & 0 & 0 \\
\hline 5a & 21 & 17 & 0 & 0 & 6 & 0 & 0 & 0 \\
\hline $5 b$ & 21 & 29 & 17 & 0 & 5 & 0 & 38 & 0 \\
\hline $7 a$ & 20 & 27 & 18 & 18 & 18 & 0 & 0 & 58 \\
\hline $7 b$ & 6 & 21 & 18 & 18 & 6 & 0 & 0 & 28 \\
\hline $7 c$ & 20 & 5 & 18 & 12 & 0 & 0 & 0 & 22 \\
\hline 8 & 7 & 23 & 35 & 12 & 31 & 0 & 0 & 0 \\
\hline 10a & 20 & 18 & 6 & 11 & 5 & 0 & 7 & 50 \\
\hline $10 \mathrm{~b}$ & 25 & 36 & 33 & 25 & 16 & 0 & 69 & 50 \\
\hline $10 \mathrm{c}$ & 6 & 6 & 11 & 12 & 0 & 0 & 20 & 50 \\
\hline 10d & 18 & 9 & 22 & 25 & 22 & 0 & 0 & 25 \\
\hline 11 & 43 & 20 & 27 & 11 & 0 & 0 & 0 & 0 \\
\hline 13 & 12 & 27 & 16 & 12 & 16 & 0 & 0 & 0 \\
\hline 14 & 31 & 30 & 33 & 11 & 10 & 56 & 0 & 0 \\
\hline
\end{tabular}

Compound 3d showed good activity against the Phytophthora infestans. Inhibition of the growth and development of the Phytophthora infestans was $80 \%$.

The activity of compounds $2 \mathrm{~d}, 3 \mathrm{~h}, 4 \mathrm{~b}, \mathrm{c}, 7 \mathrm{a}, 10 \mathrm{a}-\mathrm{c}, 14$ was relatively high. Inhibition of the growth and development of the bacteria and fungi was 50-69\% (see Table 2). 
We also tested the salts 2a-d, 3a-h, 4a-c, 5a, b, 7a-c, 8, 10a-d, 11, 13, and 14 for herbicidal activity. In the first stage of screening, we studied the activity of these compounds on five test objects: wheat, oats, sorghum, radish, and buckwheat. The concentration of each compound was $5 \mathrm{~kg}$ per hectare. The studies were carried out in two ways: spraying the soil before sowing of the seeds and spraying the vegetative part of the plants. Unfortunately, the tested substances had no herbicidal activity.

\section{Conclusions}

Thus, the alkali metal salts of the quinone mono- and dioxime were synthesized by the reaction of the corresponding quinone oxime with alkali metal hydroxide. Divalent metal salts were obtained in two stages. The first stage was the synthesis of sodium salt of the quinone oxime. The second step was the reaction of the latter with a divalent metal salt. Copper and zinc salts of [(4-oxocyclohexa-2,5-dien-1-ylidene)amino]oxidanide showed the highest insecticidal activity against the house fly and rice weevil. The death index was $90-100 \%$. Copper \{[2-methyl-4-oxo-5-(propan-2-yl)cyclohexa-2,5-dien-1-ylidene]amino $\}$ oxidanide showed good activity against the Phytophthora infestans. Inhibition of the growth and development of the Phytophthora infestans was $80 \%$.

\section{Funding}

This research received no external funding.

\section{Acknowledgments}

In this section you can acknowledge any support given which is not covered by the author contribution or funding sections. This may include administrative and technical support, or donations in kind (e.g., materials used for experiments).

\section{Conflicts of Interest}

The authors declare no conflict of interest.

\section{References}

1. Hansen, L.M.; Lorentsen, L.; Boelt, B. How to reduce the incidence of black bean aphids (Aphis fabae Scop.) attacking organic growing field beans (Vicia faba L.) by growing partially resistant bean varieties and by intercropping field beans with cereals. Acta Agriculturae Scandinavica, Section B - Soil \& Plant Science 2008, 58, 359-364, https://doi.org/10.1080/09064710701788844.

2. Kumral, N.A.; Göksel, P.H.; Aysan, E.; Kolcu, A. Life table of Tetranychus urticae (Koch) (Acari: Tetranycidae) on different Turkish eggplant cultivars under controlled conditions. Acarologia 2019, 59, 1220, https://doi.org/10.24349/acarologia/20194307.

3. Attaullah; Zahoor, M.K.; Zahoor, M.A.; Mubarik, M.S.; Rizvi, H.; Majeed, H.N.; Zulhussnain, M.; Ranian, K.; Sultana, K.; Imran, M.; Qamer, S. Insecticidal, biological and biochemical response of Musca domestica (Diptera: Muscidae) to some indigenous weed plant extracts. Saudi Journal of Biological Sciences 2020, 27, 106-116, https://doi.org/10.1016/j.sjbs.2019.05.009

4. Haddi, K.; Valbon, W.R.; Jumbo, L.O.V.; de Oliveira L.O.; Guedes R.N.C.; Oliveira E.E. Diversity and convergence of mechanisms involved in pyrethroid resistance in the stored grain weevils. Sitophilus spp. Sci Rep. 2018, 8, https://doi.org/10.1038/s41598-018-34513-5.

5. Saruhan, I. Efficacy of some entomopathogenic fungi against Aphis fabae Scopoli (Hemiptera: Aphididae). Egypt J Biol Pest Control 2018, 28, https://doi.org/10.1186/s41938-018-0096-2.

6. Xu, D.; He, Y.; Zhang, Y.; Xie, W.; Wu, Q.; Wang, S. Status of pesticide resistance and associated mutations in the two-spotted spider mite, Tetranychus urticae, in China. Pesticide Biochemistry and Physiology 2018, 150, 89-96, https://doi.org/10.1016/j.pestbp.2018.07.008. 
7. Adesanya, A.W.; Beauchamp, M.J.; Lavine, M.D. Lavine, L.C.; Zhu F.; Walsh, D.B. Physiological resistance alters behavioral response of Tetranychus urticae to acaricides. Scientific Reports volume 2019, 9, https://doi.org/10.1038/s41598-019-55708-4

8. Wang, J.N.; Hou, J.; Wu, Y.Y.; Guo, S.; Liu, Q.M.; Li, T.Q.; Gong, Z.Y. Resistance of House Fly, Musca domestica L. (Diptera: Muscidae), to Five Insecticides in Zhejiang Province, China: The Situation in 2017. Canadian Journal of Infectious Diseases and Medical Microbiology 2019, 2019, https://doi.org/10.1155/2019/4851914.

9. Freeman, J.C.; Ross, D.H.; Scott, J.G. Insecticide resistance monitoring of house fly populations from the United States. Pesticide Biochemistry and Physiology 2019, 158, 61-68, https://doi.org/10.1016/j.pestbp.2019.04.006.

10. Puthur, S.; Anoopkumar, A.N.; Rebello, S.; Aneesh, E.M. Synergistic control of storage pest rice weevil using Hypericum japonicum and deltamethrin combinations: a key to combat pesticide resistance. Environmental Sustainability 2019, 2, 411-417, https://doi.org/10.1007/s42398-019-00086-w.

11. Bhavya, M.L.; Chandu, A.G.S.; Devi, S.S. Ocimum tenuiflorum oil, a potential insecticide against rice weevil with anti-acetylcholinesterase activity. Industrial Crops and Products 2018, 126, 434-439, https://doi.org/10.1016/j.indcrop.2018.10.043.

12. Suthar, M.D.; Borad, P.K.; Bharpoda, T.M. Efficacy of different insecticides against aphid in cumin. Journal of Entomology and Zoology Studies 2018, 6, 1767-1769.

13. Abdel-Razik, M.A.R.A.M.; Heikal, H.M. Toxicity of Some Pesticides and Plant Extracts on Tetranychus urticae and its Predator, Phytoseiulus persimilis. International Journal of Zoological Research 2019, 15, 2837, https://doi.org/10.3923/ijzr.2019.28.37.

14. Levchenko, M.A.; Silivanova, E.A.; Bikinyaeva, R.K.; Balabanova, G.F. Efficacy of acetamiprid and fipronil fly baits against the housefly (Musca domestica L.) under laboratory conditions. Veterinary World 2018, 11, 953-958, https://doi.org/10.14202/vetworld.2018.953-958.

15. Abdel-Razik, M.A.R.A.M. Toxicity of Traditional, Novel and Bio-insecticides and Their Mixtures Against House Fly Musca domestica in Relation to Some Biochemical Activities. Research Journal of Environmental Toxicology 2018, 12, 1-10, https://doi.org/10.3923/rjet.2018.1.10.

16. Bertero, A.; Moretti, A.; Spicer, L.J.; Caloni, F. Fusarium Molds and Mycotoxins: Potential Species-Specific Effects. Toxins (Basel) 2018, 10, https://doi.org/10.3390/toxins10060244.

17. An, S.Q.; Potnis, N.; Dow, M.; Vorhölter, F.J.; He, Y.Q.; Becker, A.; Teper, D.; Li, Y.; Wang, N.; Bleris, L.; Tang, J.L. Mechanistic insights into host adaptation, virulence and epidemiology of the phytopathogen Xanthomonas. FEMS Microbiology Reviews 2020, 44, 1-32, https://doi.org/10.1093/femsre/fuz024.

18. Basak, S.; Guha P. A review on antifungal activity and mode of action of essential oils and their delivery as nano-sized oil droplets in food system. Journal of Food Science and Technology 2018, 55, 4701-4710, https://doi.org/10.1007/s13197-018-3394-5.

19. Lubenets, V.; Stadnytska, N.; Baranovych, D.; Vasylyuk, S.; Karpenko, O.; Havryliak, V.; Novikov, V. Thiosulfonates: The Prospective Substances against Fungal Infections. In: Fungal Infection. de Loreto É. S., Tondolo J. S.M., Eds.; IntechOpen: London, UK, 2019. https://doi.org/10.5772/intechopen.84436.

20. Lubenets, V.; Vasylyuk, S.; Monka, N.; Bolibrukh, K.; Komarovska-Porokhnyavets, O.; Baranovych, D.; Musyanovych, R.; Zaczynska, E.; Czarny, A.; Nawrot, U.; Novikov, V. Synthesis and antimicrobial properties of 4-acylaminobenzene-thiosulfoacid S-esters. Saudi Pharmaceutical Journal 2017, 25, $266-274$. https://doi.org/10.1016/j.jsps.2016.06.007.

21. Martirosyan, I.; Pakholiuk, O.; Semak, B.; Lubenets, V.; Peredriy, O. Investigation of wear resistance of cotton-polyester fabric with antimicrobial treatment. In: Advanced Manufacturing Processes, Tonkonogyi V., Ivanov V., Trojanowska J., Oborskyi G., Edl M., Kuric I., Pavlenko I., Dasic P., Eds.; Part of the Lecture Notes in Mechanical Engineering book series; Springer: Cham, Switzerland, 2020; pp. 433-441. https://doi.org/10.1007/978-3-030-40724-7_44.

22. Martyrosian, I.A., Pakholiuk, O.V., Semak, B.D., Komarovska-Porokhniavets, O.Z., Lubenets, V.I., Pambuk, S.A. New Technologies of Effective Protection of Textiles Against Microbiological Damage. Nanosystems, $\quad$ Nanomaterials, $\quad$ Nanotechnologies $\quad \mathbf{2 0 1 9}, \quad$ 17, $621-636$. https://www.imp.kiev.ua/nanosys/media/pdf/2019/4/nano_vol17_iss4_p0621p0636_2019.pdf.

23. Nicholls, A.J.; Barber, T.; Baxendale, I.R. The Synthesis and Utility of Metal-Nitrosophenolato Compounds-Highlighting the Baudisch Reaction. Molecules 2019, 24, 4018. https://doi.org/10.3390/molecules24224018.

24. Konovalova, S.A.; Avdeenko, A.P.; Goncharova, S.A. Halogenation of N-substituted p-quinone monoimines and p-quinone monooxime ethers: XV. Synthesis and bromination of 4-(cinnamoyloxyimino)cyclohexa-2,5-dienones. Russian Journal of Organic Chemistry 2016, 52, 939-945, https://doi.org/10.1134/S1070428016070034.

25. Avdeenko, A.P.; Pirozhenko, V.V.; Shishkina, S.V.; Konovalova, S.A.; Ludchenko, O.N. Halogenation of $\mathrm{N}$-substituted p-quinone monoimines and p-quinone monooxime esters: VII. Halogenation of 4aroyl(arylsulfonyl)imino- and 4-aroyl(arylsulfonyl)-oxyimino-2,6-diisopropylcyclohexa-2,5-dien-1-ones. Russian Journal of Organic Chemistry 2008, 44, 542-552. https://doi.org/10.1134/S107042800804013. 
26. Avdeenko, A.P.; Konovalova, S.A.; Il'chenko, A.Ya.; Glinyanaya, N.M. Halogenation of N-substituted pquinone imines and p-quinone oxime esters: III. Regioselectivity in the halogenation of $\mathrm{N}$ aroyl(arylsulfonyl)oxyimino-2,5-cyclohexadienones. Russian Journal of Organic Chemistry 2006, 42, 5665. https://doi.org/10.1134/S1070428006010106.

27. Avdeenko, A.P.; Konovalova, S.A. Quinone imines: from anti-cancer drugs to molecular computers: monograph. Donbas State Engineering Academy: Kramatorsk, Ukraine, 2018; pp. 238-388. (In Russian). ISBN 978-617-7415-40-3; 978-966-379-835-6

28. Kuz'menko, L.; Avdeenko, A.; Konovalova, S.; Vasylyuk, S.; Fedorova, O.; Monka, N.; Krychkovska, A.; Lubenets, V. Synthesis and study of pesticidal activity of some N-arylthio-1,4-benzoquinone imines. Biointerface Research in Applied Chemistry 2019, 9, 4232-4238. https://doi.org/10.33263/BRIAC95.232238.

29. Abuelazm, M.G.; El-Gammal, O.A.; Mandour, S.A. Binuclear metal complexes of a symmetric polydentate donor hydrazone: Synthesis, spectral characterization, DNP DFT computational and biological studies. Biointerface Research in Applied Chemistry 2019, 9, 4547-4559. https://doi.org/10.33263/BRIAC96.547559.

30. Narasaiah, B.P.; Mandal, B.K. Bio-fabricated $\mathrm{CuO}$ NPs as green catalyst towards remediation of environmental pollutants. Letters in Applied NanoBioScience 2019, 8, 597-603. https://doi.org/10.33263/LIANBS83.597603.

31. Rao D.P. A review on versatile applications of novel Schiff bases and their metal complexes. Letters in Applied NanoBioScience 2019, 8, 675-681. https://doi.org/10.33263/LIANBS84.675681

32. Avdeenko, A.P.; Glinyanaya, N.M.; Pirozhenko, V.V. Synthesis and Spectral Study of Salts Derived from Quinone Mono- and Dioximes. Russian Journal of Organic Chemistry 1999, 35, 1480-1487.

33. Weygand-Hilgetag. Organisch-chemische Experimentierkunst. 3rd ed.; Hilgetag, G.; Martini, A. Eds.; Johann Ambrosius Barth: Leipzig, Germany, 1964; pp. 328-365.

34. Rück-Braun, K.; Priewisch, B. 31.22.1.1.1 Method 1: Nitrosation of Phenols by Nitrous Acid. Science of Synthesis 2007, 31, 1322. https://doi.org/10.1055/sos-SD-031-01513

35. Singh, N.; Stephenson, D. ${ }^{14} \mathrm{~N}$ NQR study of selected 1,4-benzoquinonedioximes. Hyperfine Interact 2010 , 197, 309-315, https://doi.org/10.1007/s10751-010-0239-7

36. Sánchez-Calvo, J.M.; Barbero, G.R.; Guerrero-Vásquez, G.; Durán, A.G.; Macías, M.; Rodríguez-Iglesias, M.A.; Molinillo, J.M.G.; Macías, F.A. Synthesis, antibacterial and antifungal activities of naphthoquinone derivatives: a structure-activity relationship study. Medicinal Chemistry Research 2016, 25, 1274-1285, https://doi.org/10.1007/s00044-016-1550-x. 